\title{
CHRONOLOGY OF RED DUNE AGGRADATIONS OF SOUTH INDIA AND ITS PALAEO-ENVIRONMENTAL SIGNIFICANCE
}

\author{
LINTO ALAPPAT ${ }^{1}$, PALANIANDY SERALATHAN ${ }^{2}$, ANIL D. SHUKLA ${ }^{1}$, KYTH PILLAI THRIVIKRAMJI ${ }^{3}$ \\ and ASHOK KUMAR SINGHVI ${ }^{1}$ \\ ${ }^{1}$ Geosciences Division, Physical Research Laboratory, Ahmedabad, India \\ ${ }^{2}$ Department of Marine Geology and Geophysics, Cochin University of Science and Technology, \\ Kerala, India \\ ${ }^{3}$ UGC Emeritus Fellow, Dept. of Geology, University of Kerala, Kariavattom Campus, Trivandrum, India
}

Received 31 January 2013

Accepted 17 June 2013

\begin{abstract}
Red sand dunes occur in the coastal plains of south east and west of Tamil Nadu, India between the co-ordinates of $8^{\circ} 00^{\prime}$ to $9^{\circ} 30^{\prime} \mathrm{N} ; 7^{\circ} 18^{\prime}$ to $79^{\circ} 00^{\prime} \mathrm{E}$. OSL dating of these sands indicated aggradations between $\sim 16-9 \mathrm{ka}$ and $\sim 9-3 \mathrm{ka}$ in the west and east coasts respectively. Dating results from inland red dunes at the foothills of Western Ghats show a break in deposition at $\sim 6 \mathrm{ka}$ and aggradation since $\sim 2 \mathrm{ka}$. The sand aggradations in the west coast occurred during the transition period when SW monsoon in the area was re-establishing. The dunes attained their stability by $9 \mathrm{ka}$. In the coastal region, the aggradations were controlled by sea level changes and a local recycling of earlier dunes (in the east coast). In the inland areas, the dune building was controlled by sand supply from fluvial sources.
\end{abstract}

Keywords: red sand dunes, OSL dating, Pleistocene, Holocene, chronology, sand aggradations.

\section{INTRODUCTION}

Red dunes in coastal and in desert settings have been extensively studied (Folk, 1976; Nageswara Rao et al., 2006; Roskin et al., 2012; Singhvi and Porat, 2008; Zhang et al., 2008 and Zheng and Wei, 1998). The key questions of the studies on red dunes have been the environmental conditions needed for their formation and the timing and duration of reddening process (e.g., Gardner and Pye, 1981 and references therein). Traditionally, the degree of reddening was linked to antiquity (Folk, 1976 and Walker, 1967), however later studies have shown that the colour and age were not related (Roskin et al., 2012). The dune reddening occurs via progressive loss of ferro- magnesian minerals through hydrolysis (Berner, 1969; Van Houten, 1968 and Walker, 1967), with cyclic precipitation and temperature being the major factors for dune reddening (Folk, 1976; Gardner and Pye, 1981 and Pye and Tsoar, 2009). In humid tropics the reddening can occur over time scales of centuries.

Red sands in this region (Fig. 1) have been studied for their colour, sedimentology, geochemistry, palaeoclimate, archaeology and economic significance (Chandrasekharan and Murugan, 2001; Gardner and Martingell, 1990; Gardner, 1981; Jayangondaperumal et al., 2012; Joseph et al., 1999; Joseph et al., 2002; Joseph and Thrivikramji, 2005 and Thrivikramji et al., 2008). The red coating of these sands is due to iron oxides formed by in-situ weathering of garnet (Gardner and Pye, 1981).

Corresponding author: L. Alappat

e-mail: lintoalappat@yahoo.co.uk 
Though the environmental conditions for dune aggradation are understood, their chronometry remained unresolved, the exception being the recent work by Jayangondaperumal et al. (2012). Earlier studies on absolute dating of red sands using luminescence dating (e.g., Singhvi et al., 1986 and Zhang et al., 2008) have shown that this method provides robust ages.

Terrestrial records of environmental changes in the southern part of Peninsular India are limited and are largely based on pollen analysis (Bera et al., 1997 and Bera et al., 1995), radiocarbon dating and stable isotopes of carbon in peats (Rajagopalan et al., 1997 and Sukumar et al., 1993) and coastal wetlands (Nair et al., 2010; Kumaran et al., 2005; Limaye et al., 2010 and Padmalal et al., 2011). Most coastal dunes in east and west coast show middle to late Holocene age (Alappat et al., 2011; Kunz et al., 2010), while the red dune sands are dated to Late Pleistocene (Jayangondaperumal et al., 2012). In the east coast, Jayangondaperumal et al. (2012) reported that inland dunes of ages $>11 \mathrm{ka}$, are associated with lower sea level and the near coastal red sands were deposited during the high sea level at $\sim 6 \mathrm{ka}$. The present study had the objectives to develop a chronology for these dunes using OSL dating along with an assessment of effects of reddening on bleaching and radiation dosimetry.

Red dunes in the east coast (referred as "teri sands/ teris' in literatures) are categorized as inland, coastal and near-coastal (teris) dunes by Joseph et al. (1997; 1999). According to the standard Tamil dictionary, teri means 'a heap of sand'. Jeyangondaperumal et al. (2012) used 'waste land' because the local people called so as it was useless for agriculture (personal communication). The near coastal dunes are continuous coast parallel deposits from Kanyakumari to south Rameshwaram (Fig. 1). The coastal dunes occur as discontinuous ridges further inland and the thickest deposits are at Kudiramozhi and Sattankulam (SK-1) (Fig. 1). The inland dune occurs at the foothills of Western Ghats as random outcrops (Fig. 1). Red sands in the coastal dunes occur directly over the basement sandstone formation and the near coastal dunes rest on a discrete calcrete horizon.

\section{STUDY AREA}

The study area was bounded by latitudes of $\mathrm{N} 8^{\circ} 00^{\prime}$ to $9^{\circ} 30^{\prime}$ and longitudes of $\mathrm{E} 77^{\circ} 18^{\prime}$ to $79^{\circ} 00^{\prime}$ (Fig. 1). In the west coast, a section at Muttom $\left(8^{\circ} 07^{\prime} 56^{\prime \prime} \mathrm{N}\right.$; $\left.77^{\circ} 19^{\prime} 84^{\prime \prime} \mathrm{E}\right)$ was examined. In the east coast, two sections viz., SK-1 $\left(8^{\circ} 22^{\prime} 18^{\prime \prime} \mathrm{N} ; 7^{\circ} 55^{\prime} 20^{\prime \prime} \mathrm{E}\right)$ and SK-2 $\left(8^{\circ} 28^{\prime} 43^{\prime \prime} \mathrm{N} ; 78^{\circ} 01^{\prime} 09^{\prime \prime} \mathrm{E}\right)$ and two inland sections at Vadakkankulam, VK-1 $\left(8^{\circ} 15^{\prime} 56^{\prime \prime N} ; 77^{\circ} 35^{\prime} 00^{\prime \prime E}\right)$ and Panagudi, PG-1 $\left(8^{\circ} 22^{\prime} 02^{\prime \prime} \mathrm{N} ; 77^{\circ} 35^{\prime} 00^{\prime \prime E}\right)$ were examined (Fig. 1).

At Muttom, a $\sim 8-10 \mathrm{~m}$ thick deeply gullied NNWSSE trending dune, spread over $3 \mathrm{~km}^{2}$ overlying bed rock occurs against an elevated upland. The average annual rainfall at this location is $\sim 1300 \mathrm{~mm}$, including both the $\mathrm{SW}$ and NE monsoon. Red dunes in the east coast, receive 700-1000 mm annual rainfall mainly during NE monsoon (Indian Meteorological Department, http://www.imd.gov.in/section/hydro/distrainfall/districtr ain.html).

\section{Regional geology and geomorphology}

The geology of the area comprises Archaen granulitic rocks, primarily peninsular gneiss (garnet-sillimanitegraphite gniess) and charnockite gneiss. The coastal area has Pleistocene and recent fluvial, fluvio-marine and marine deposits. The Cuddalore formation of Mio- Pliocene age is exposed towards the north east.

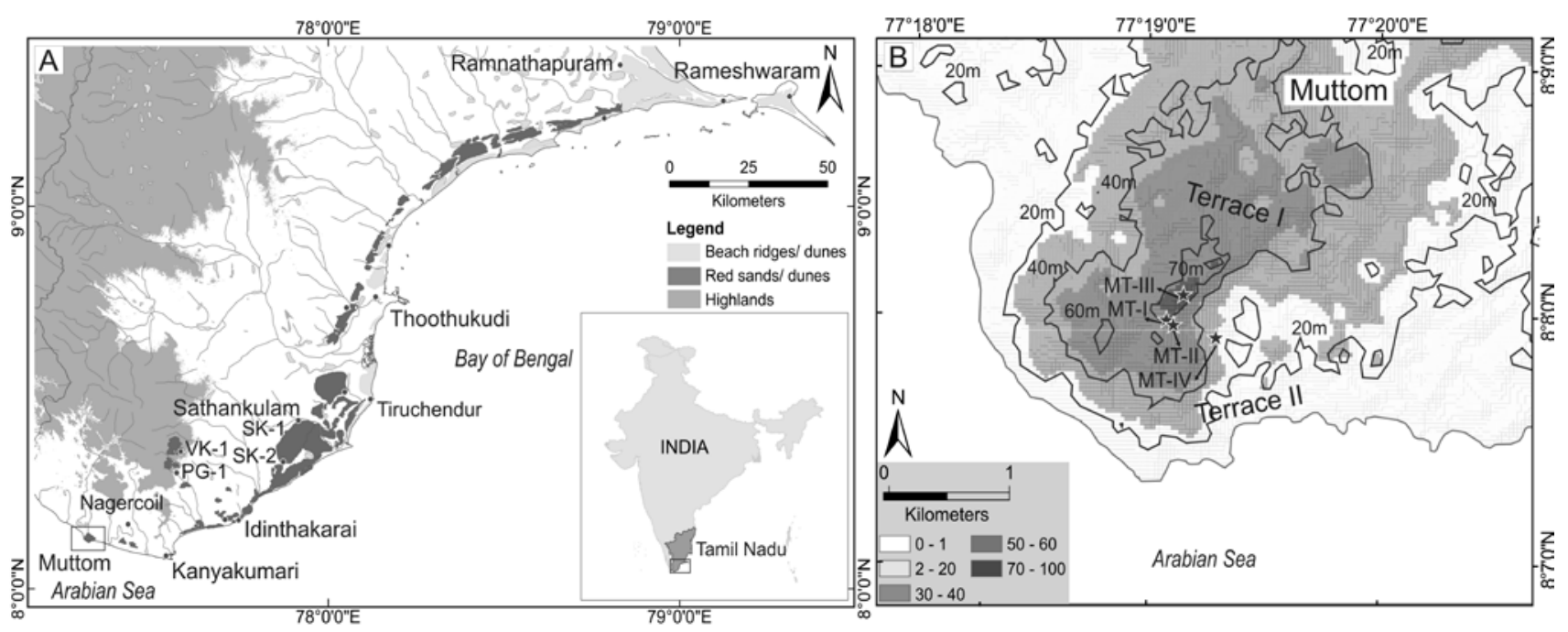

Fig. 1. A) Map of the study area, with sample locations in the west and east coast (both coastal and inland dunes) are marked. Inset showing Tamil $\mathrm{Nadu}$, India where red dunes are seen. B) Digital elevation model of Muttom in the west coast with sections and terrace contours marked. 
At Muttom, the red sands occur as a dune against a promontory into the Arabian Sea (Fig. 1). River Valliyar joins the Arabian Sea at the North West side of this promontory. This landscape is cut across by modern dunes, beach ridges, swales and beaches towards coast and exhibits badland topography with weathering and gully erosion exposing up to $\sim 10 \mathrm{~m}$ thick sand unit in its central part. Generally the red sands overlie laterized country rock with slope towards SE. Dunes in the east coast are cut by a number of rivers and streams. The near coastal and coastal dunes are separated by numerous discontinuous coast parallel lagoons and swales. The floodplains of the rivers restrict the dune development as discontinuous patches.

\section{Sample collection}

Red dunes at Muttom show two terraces. Terrace I is at $\sim 30-75 \mathrm{~m}$ above $\mathrm{msl}$ and one $\mathrm{km}$ inland and, terrace II is at a lower level at $\sim 10-25 \mathrm{~m}$ above m.s.l. and $\sim 300 \mathrm{~m}$ inland (Fig. 1). Eight samples from four profiles in the terrace-I were collected (Fig. 1). Fig. 1 provides the location of these profiles. The sand deposits were laterally discontinuous, indurated and overlain by a $<1 \mathrm{~m}$ thick loose sand. The indurated sands were devoid of sedimentary structures and the upper sands had dark and light parallel laminations. The dune sections were deeply gullied and monoliths of hardened sand with vertical cracks were seen. Two profiles (MT-I, II; 3.5-6 m thick) at the NW side of the dune at $\sim 50 \mathrm{~m}$ apart were excavated. Fig. 2 provides the lithologs and sample location. The sands comprised of consolidated, brownish red medium sand
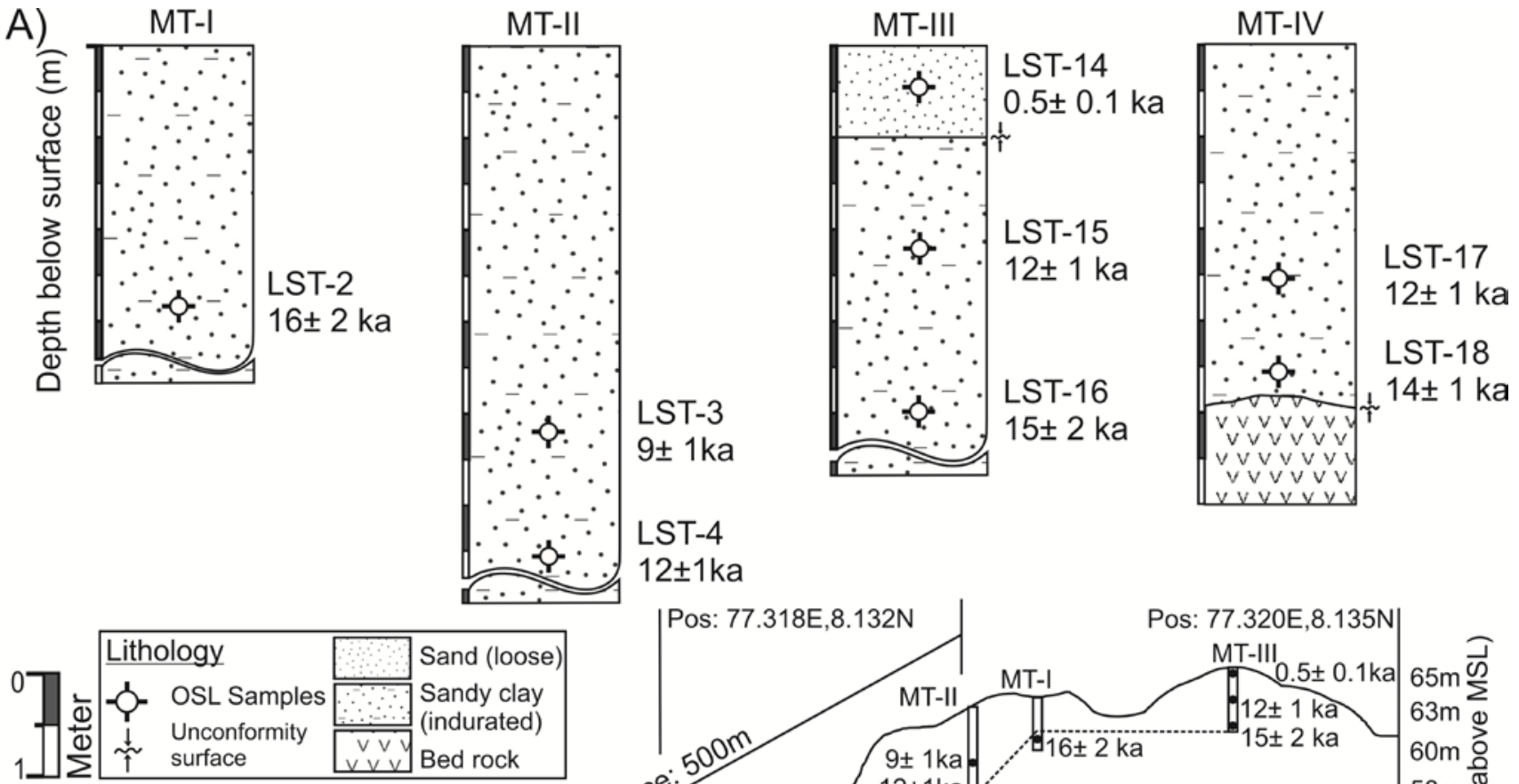

B)

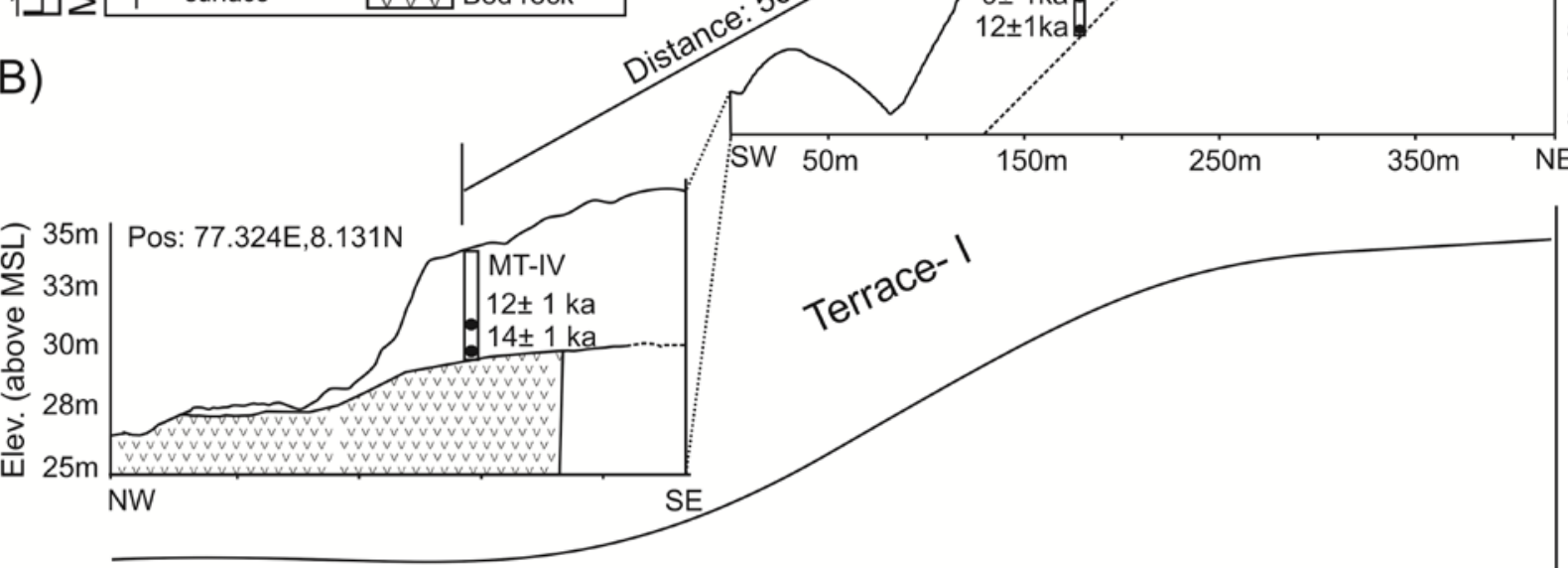

Fig. 2. A) Illustrations showing the stratigraphic succession in the excavated dune sections at Muttom along with OSL sample positions and ages, $B$ ) showing the overall view and elevation of the dune field in the transect, where different sections are located. 
grains intercalated with clay matrix. MT-III was a $9 \mathrm{~m}$ section in the central part and only upper $4.5 \mathrm{~m}$ could be sampled due to logistical difficulties. Except $1 \mathrm{~m}$ of loose sand on top, the lower $8 \mathrm{~m}$ of sand appeared indurated (shown as sandy clay in Fig. 2) consisting of brownish red sandy horizon with interstitial clay. From the lower unit, two samples, LST-15 and LST-16 at 2.3 and $4 \mathrm{~m}$ depths were analyzed. Sample LST-14 was collected from the upper unconsolidated, massive orange red fine sand. MT-IV consisted of a $4 \mathrm{~m}$ thick unit of brownish red, consolidated medium sand at the south east part of the upper terrace underlain by weathered country rock at the base. Two samples, LST-17, 18 at depths of $3.7 \mathrm{~m}$ and $2.6 \mathrm{~m}$ were collected from this section.

In the east coast, two sections in the coastal dunes from the Sattankulam teri (SK-1, 2) and two in the inland dunes (VK-1, PG-1) at the foot hills of W. Ghats were excavated (Fig. 3). Section SK-1 was $3 \mathrm{~m}$ and SK-2 was $2.5 \mathrm{~m}$ deep. Four samples (LST-20 to 23) were collected from SK-1 and two (LST-24 and 25) from SK-2 were dated.

Section VK-1 was dug across a dune profile in which the stratigraphy comprised of $2.2 \mathrm{~m}$ thick slightly indurated orange red medium sand at the lower part, overlain by $2.3 \mathrm{~m}$ yellowish red medium sand at the top. Five samples (LST 5-9) were collected from this section at various depths (Table 1). The second section at PG-1, a

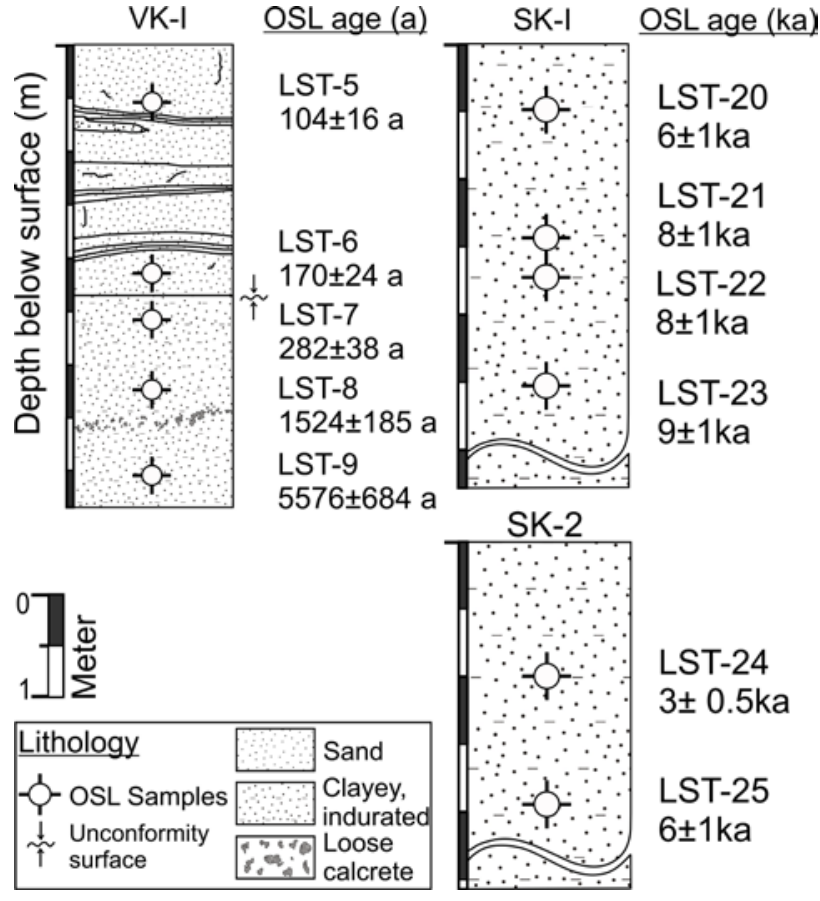

Fig. 3. Illustration showing the stratigraphic succession, OSL sample position and ages for the sections in the inland dune (VK-1) and coastal dunes (SK-1 and -2) in the east coast.

Table 1. Shows the depth, moisture content and details of dose rate and luminescence measurements of samples in the study. $D_{e}$ values are calculated from the weighted mean of distribution and errors are shown as standard errors.

\begin{tabular}{|c|c|c|c|c|c|c|c|c|c|c|c|c|}
\hline Section & $\begin{array}{c}\text { Sample } \\
\text { ID }\end{array}$ & $\begin{array}{c}\text { Depth } \\
(\mathrm{cm})\end{array}$ & $\begin{array}{c}\text { Moisture } \\
\text { content } \\
(\%)\end{array}$ & $\mathrm{K}(\%)$ & Th (ppm) & U (ppm) & $\begin{array}{c}\text { Cosmic } \\
\text { dose } \\
\left(\mathrm{mGy} \mathrm{a}^{-1}\right)\end{array}$ & $\begin{array}{l}\text { Dose rate } \\
\left(\mathrm{mGy} \mathrm{a}^{-1}\right)\end{array}$ & $\begin{array}{c}D_{\mathrm{e}}-W t . \\
\text { mean (Gy) }\end{array}$ & $n$ & $\begin{array}{c}\text { Over- } \\
\text { dispersion } \\
(\%)\end{array}$ & Age (ka) \\
\hline MT-I & LST-2 & 280 & $8 \pm 2$ & $0.34 \pm 0.01$ & $161.0 \pm 1.6$ & $7.0 \pm 0.1$ & $0.12 \pm 0.01$ & $10.7 \pm 1.1$ & $168 \pm 2$ & 179(190)‡ & f 38 & $16 \pm 2$ \\
\hline \multirow{2}{*}{ MT-II } & LST-3 & 420 & $8 \pm 2$ & $0.29 \pm 0.01$ & $228.0 \pm 2.3$ & $9.0 \pm 0.1$ & $0.10 \pm 0.01$ & $14.7 \pm 1.5$ & $126 \pm 2$ & $43(65) \ddagger$ & 38 & $9 \pm 1$ \\
\hline & LST-4 & 560 & $8 \pm 2$ & $0.37 \pm 0.01$ & $187.0 \pm 1.9$ & $7.4 \pm 0.1$ & $0.08 \pm 0.01$ & $12.1 \pm 1.2$ & $142 \pm 2$ & $97(101) \ddagger$ & 35 & $12 \pm 1$ \\
\hline \multirow{3}{*}{ MT-III } & LST-14 & 40 & $15 \pm 5$ & $0.21 \pm 0.01$ & $149.0 \pm 1.5$ & $6.6 \pm 0.1$ & $0.18 \pm 0.02$ & $9.2 \pm 0.9$ & $4.6 \pm 0.1$ & $39(60) \ddagger$ & 17 & $501 \pm 51^{*}$ \\
\hline & LST-15 & 230 & $15 \pm 5$ & $0.25 \pm 0.01$ & $118.0 \pm 1.2$ & $5.4 \pm 0.1$ & $0.13 \pm 0.01$ & $7.4 \pm 0.7$ & $90 \pm 1$ & 86(142)‡ & 44 & $12 \pm 1$ \\
\hline & LST-16 & 400 & $15 \pm 5$ & $0.29 \pm 0.01$ & $130.0 \pm 1.3$ & $5.7 \pm 0.1$ & $0.10 \pm 0.01$ & $8.0 \pm 0.8$ & $124 \pm 2$ & $120(135) \ddagger$ & 48 & $15 \pm 2$ \\
\hline \multirow{2}{*}{ MT-IV } & LST-17 & 200 & $5 \pm 2$ & $0.26 \pm 0.01$ & $107.0 \pm 1.1$ & $5.1 \pm 0.1$ & $0.14 \pm 0.01$ & $7.5 \pm 0.8$ & $91 \pm 1$ & 102(114)‡ & 53 & $12 \pm 1$ \\
\hline & LST-18 & 320 & $5 \pm 2$ & $0.19 \pm 0.01$ & $100.0 \pm 1.0$ & $4.9 \pm 0.1$ & $0.11 \pm 0.01$ & $6.9 \pm 0.7$ & $97 \pm 1$ & $84(97) \ddagger$ & 57 & $14 \pm 1$ \\
\hline \multirow{5}{*}{ VK-1 } & LST-5 & 60 & $6 \pm 2$ & $2.10 \pm 0.08$ & $47.9 \pm 12.1$ & $6.6 \pm 0.5$ & $0.18 \pm 0.02$ & $6.0 \pm 0.8$ & $0.63 \pm 0.05$ & $15(15)$ & 44 & $104 \pm 16^{*}$ \\
\hline & LST-6 & 220 & $6 \pm 2$ & $2.03 \pm 0.08$ & $23.7 \pm 4.4$ & $2.2 \pm 1.3$ & $0.13 \pm 0.01$ & $3.7 \pm 0.5$ & $0.64 \pm 0.04$ & $9(12)$ & 22 & $170 \pm 24^{*}$ \\
\hline & LST-7 & 250 & $6 \pm 2$ & $3.46 \pm 0.09$ & $14.7 \pm 1.9$ & $0.7 \pm 0.5$ & $0.13 \pm 0.01$ & $4.2 \pm 0.4$ & $1.2 \pm 0.1$ & $10(12)$ & 35 & $282 \pm 38^{*}$ \\
\hline & LST-8 & 320 & $6 \pm 2$ & $2.37 \pm 0.08$ & $32.5 \pm 5.7$ & $4.4 \pm 1.2$ & $0.11 \pm 0.01$ & $5.0 \pm 0.6$ & $7.5 \pm 0.2$ & $15(20)$ & 27 & $2 \pm 0$ \\
\hline & LST-9 & 400 & $6 \pm 2$ & $2.04 \pm 0.08$ & $21.8 \pm 3.8$ & $2.4 \pm 1.1$ & $0.10 \pm 0.01$ & $3.6 \pm 0.4$ & $20 \pm 1$ & $32(36) \ddagger$ & 51 & $6 \pm 1$ \\
\hline \multirow{3}{*}{ PG-1 } & LST-10 & 50 & $6 \pm 2$ & $1.87 \pm 0.09$ & $14.1 \pm 2.8$ & $1.7 \pm 0.8$ & $0.18 \pm 0.02$ & $3.0 \pm 0.4$ & $0.70 \pm 0.06$ & $8(12)$ & - & $233 \pm 34^{*}$ \\
\hline & LST-11 & 250 & $6 \pm 2$ & $2.15 \pm 0.08$ & $9.7 \pm 1.6$ & $0.9 \pm 0.4$ & $0.13 \pm 0.01$ & $2.8 \pm 0.3$ & $0.33 \pm 0.03$ & $9(12)$ & - & $119 \pm 18^{*}$ \\
\hline & LST-12 & 322 & $6 \pm 2$ & $2.00 \pm 0.08$ & $10.2 \pm 1.8$ & $1.4 \pm 0.5$ & $0.11 \pm 0.01$ & $2.8 \pm 0.3$ & $1.9 \pm 0.1$ & $8(12)$ & - & $697 \pm 89^{*}$ \\
\hline \multirow{4}{*}{ SK-1 } & LST-20 & 50 & $6 \pm 2$ & $0.09 \pm 0.05$ & $68.5 \pm 5.4$ & $8.2 \pm 1.3$ & $0.18 \pm 0.02$ & $5.7 \pm 0.7$ & $35 \pm 1$ & $9(12)$ & 25 & $6 \pm 1$ \\
\hline & LST-21 & 150 & $6 \pm 2$ & $0.12 \pm 0.05$ & $69.5 \pm 5.8$ & $8.7 \pm 1.2$ & $0.15 \pm 0.02$ & $5.8 \pm 0.7$ & $45 \pm 1$ & $33(41) \ddagger$ & 46 & $8 \pm 1$ \\
\hline & LST-22 & 180 & $6 \pm 2$ & $0.12 \pm 0.05$ & $79.8 \pm 7.8$ & $8.0 \pm 1.0$ & $0.14 \pm 0.01$ & $6.3 \pm 0.7$ & $49 \pm 1$ & $31(38) \ddagger$ & 25 & $8 \pm 1$ \\
\hline & LST-23 & 250 & $6 \pm 2$ & $0.00 \pm 0.00$ & $51.3 \pm 6.9$ & $6.6 \pm 0.5$ & $0.13 \pm 0.01$ & $4.3 \pm 0.5$ & $40 \pm 1$ & $36(45) \ddagger$ & 38 & $9 \pm 1$ \\
\hline \multirow{2}{*}{ SK-2 } & LST-24 & 100 & $6 \pm 2$ & $0.38 \pm 0.07$ & $22.3 \pm 3.4$ & $4.2 \pm 1.1$ & $0.16 \pm 0.02$ & $2.6 \pm 0.4$ & $8.3 \pm 0.3$ & $19(26) \ddagger$ & 23 & $3 \pm 0$ \\
\hline & LST-25 & 200 & $6 \pm 2$ & $0.54 \pm 0.09$ & $22.4 \pm 3.0$ & $2.7 \pm 0.9$ & $0.14 \pm 0.01$ & $2.4 \pm 0.3$ & $13.6 \pm 0.4$ & 18(31)‡ & 23 & $6 \pm 1$ \\
\hline
\end{tabular}

f-Single grain measurements; *- Age in years 
$4 \mathrm{~m}$ thick wall was excavated consisting of red colored fine to medium loose, massive sand and 3 samples (LST 10-12) were collected for OSL dating at different intervals.

\section{OPTICALLY STIMULATED LUMINESCENCE DATING}

Dry sieving indicated that sands were of fine to medium size grains. The grain size fractions of $150-210 \mu \mathrm{m}$ were treated with $1 \mathrm{~N}$ hydrochloric acid and $30 \%$ hydrogen peroxide to remove carbonates and organic matter respectively. Quartz grains were magnetically separated from feldspar and heavy magnetic minerals using Frantz Magnetic separator at $10 \mathrm{kGs}$ (Porat, 2006). The grains were then etched using $40 \%$ hydrofluoric acid (HF) for $\sim 80$ minutes, followed by $12 \mathrm{~N} \mathrm{HCl}$ to remove the alpha skin and residual feldspar contamination. The remaining portion was then re-sieved through $150 \mu \mathrm{m}$ mesh. The purity of the extracted quartz fraction was checked using their Infrared Stimulated Luminescence.

Luminescence measurements were carried out in a Riso- TL/OSL DA-20 reader fitted with a single grain attachment using green laser, and a ${ }^{90} \mathrm{Sr} /{ }^{90} \mathrm{Y}$ beta source. For single grain measurements, typically $\sim 1500$ grains per sample were measured. For samples measured for single aliquot method, $\sim 100-200$ grains on each aliquot was measured with blue light as the stimulation source. A similar single aliquot regenerative dose (SAR) protocol (Wintle and Murray, 2006) was used for both multigrain and single grain (adapted for single grain measurements) measurements. Fig. 4 shows the results of preheat plateau and dose recovery test of a selected sample carried out to determine an optimum SAR protocol. The $\mathrm{D}_{\mathrm{e}}$ was calculated after subtracting the early background (Singhvi and Lang, 1998). Average $\mathrm{D}_{\mathrm{e}}$ (weighted mean) was calculated and uncertainties are expressed as standard error. The over dispersion of the $D_{e}$ distribution was calculated
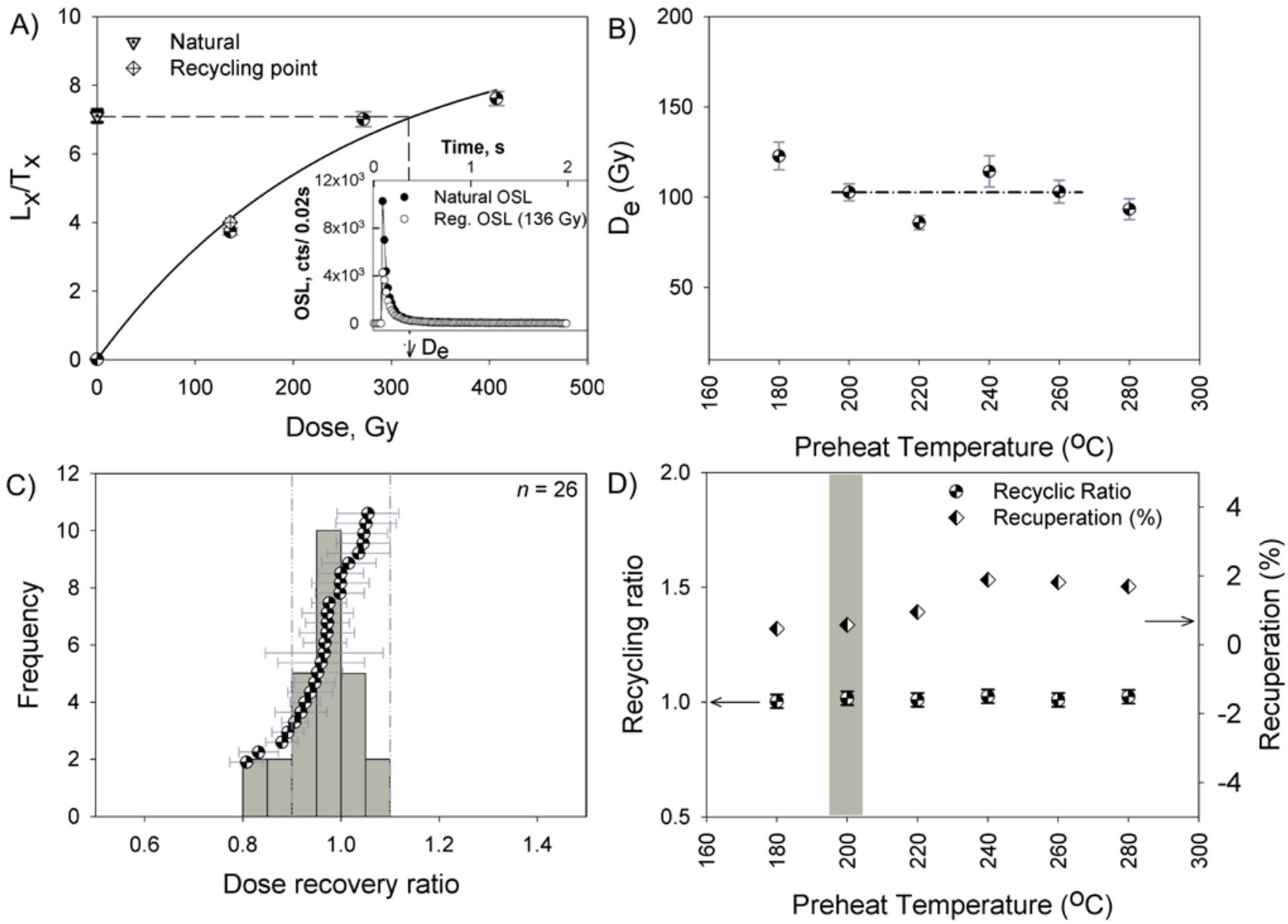

Fig. 4. A) Diagram showing the growth curve of a selected grain from sample LST-2 in which both natural and regenerative decay curve for $2 s$ have shown. Diagrams showing the B) preheat plateau between $200-260^{\circ} \mathrm{C}$ for sample LST-17. C) the distribution of measured aliquots for dose recovery (ratio of measured to known laboratory dose) and D) recycling and recuperation (Sample LST-17). $200^{\circ} \mathrm{C}$ was chosen as the measurement temperature in which it had shown minimum recuperation. 
using the central age model (Galbraith et al., 1999). Bleaching test to estimate attenuation of light due to the red coating on the sand grains was also carried out (Fig. 6).

Annual dose rates were calculated from the activity concentrations of decay chains ${ }^{238} \mathrm{U},{ }^{232} \mathrm{Th}$ (Fig. 5) and ${ }^{40} \mathrm{~K}$ measured using the High Purity Germanium (HPGe) detector (Table 1). Dried samples were packed in airtight plastic containers to prevent radon loss and stored for 3-4 weeks to establish equilibrium before counting. The dose rate conversion factors of Adamiec and Aitken (1998) and beta attenuation factors of Mejdahl (1979) were applied for calculation. The cosmic dose rate was calculated using Prescott and Hutton (1994).

\section{RESULTS}

Laboratory bleaching studies were carried out using a sunlamp (Osram Ultravitalux $300 \mathrm{~W}$ sunlamp bulb), filtered through a $7 \mathrm{~mm}$ borax glass for various exposure duration. For this, the sample as received was exposed as a monolayer to varying duration of sunlamp exposure and the ratio of weight normalized signal after bleaching, to the natural sample was computed (Fig. 6). One minute of sunlamp exposure reduced the natural signal to $\sim 70 \%$ of the natural signal and $10 \mathrm{~min}$ exposure resulted in its reduction to near background level (6\%) (Fig. 6). This along with repeated cycles of erosion and transportation prior to deposition of the grain implied that the grains were well bleached prior to deposition.

Samples from the inland dunes depicted lower luminescence sensitivity ( 240 photon counts/mg/Gy) compared to those from coastal dunes ( 2200 photon counts $/ \mathrm{mg} / \mathrm{Gy}$ ) leading to the rejection of many aliquots for the calculation of final $D_{e}$ 's. These samples had shown high recuperation ( $>5 \%$ natural) and poor recycling ratios $(>10 \%)$. The samples in west coast showed higher dose values (90-168 Gy) and unusually higher dose rates ( 7 and $15 \mathrm{~Gy} / \mathrm{ka}$ ) giving ages of 16 to $9 \mathrm{ka}$. Ages for coastal and inland dunes in the east coast ranged from 9-3 $\mathrm{ka}$ and 6-0.1 ka respectively. The dosimetric, sample details and OSL ages are given in Table 1 and stratigraphic position of the samples are shown in Figs. 2 and 3 .

\section{DISCUSSION}

Higher concentration of $\mathrm{U}$, Th and low $\mathrm{K}$ values indicate that most of the dose in the sample comes from $\mathrm{U}$ and Th. Previous studies have examined the dosimetric implication of possible co-precipitation of $\mathrm{U}$ with $\mathrm{Fe}$ minerals (Duff et al., 2002) and downward migration of $U$ and Th in the profile (Singhvi et al., 1986 and Zhang et al., 2008). No systematic increase or decrease in the $U$ and Th concentration with depth over the profile were seen and the activity ratios were consistent for different daughter nuclides in the same series (Fig. 5) suggesting radioactive equilibrium and absence of leaching down the profile.

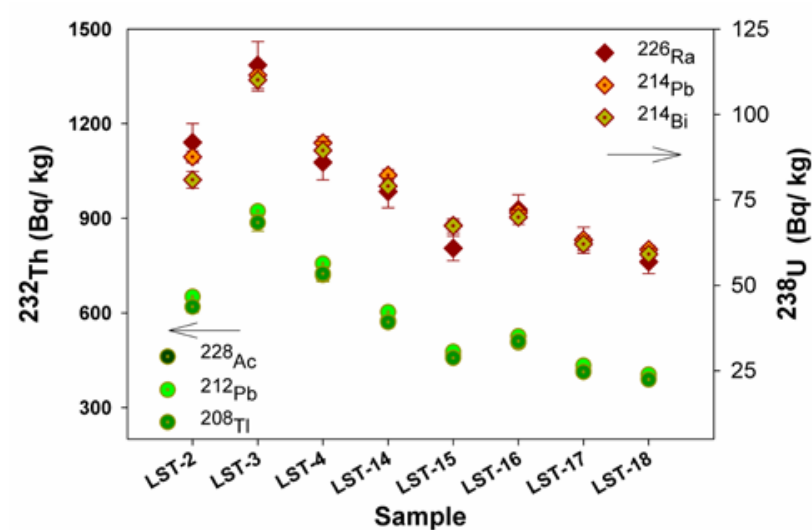

Fig. 5. Diagram showing the activities of radioactive daughter isotopes from the decay chain of $U\left({ }^{226} \mathrm{Ra},{ }^{214} \mathrm{~Pb}\right.$ and $\left.{ }^{214} \mathrm{Bi}\right)$ and $\mathrm{Th}\left({ }^{228} \mathrm{Ac},{ }^{212} \mathrm{~Pb}\right.$, $\left.{ }^{208} \mathrm{TI}\right)$ from selected samples. It was observed that the activities are similar, indicating secular radioactive equilibrium.

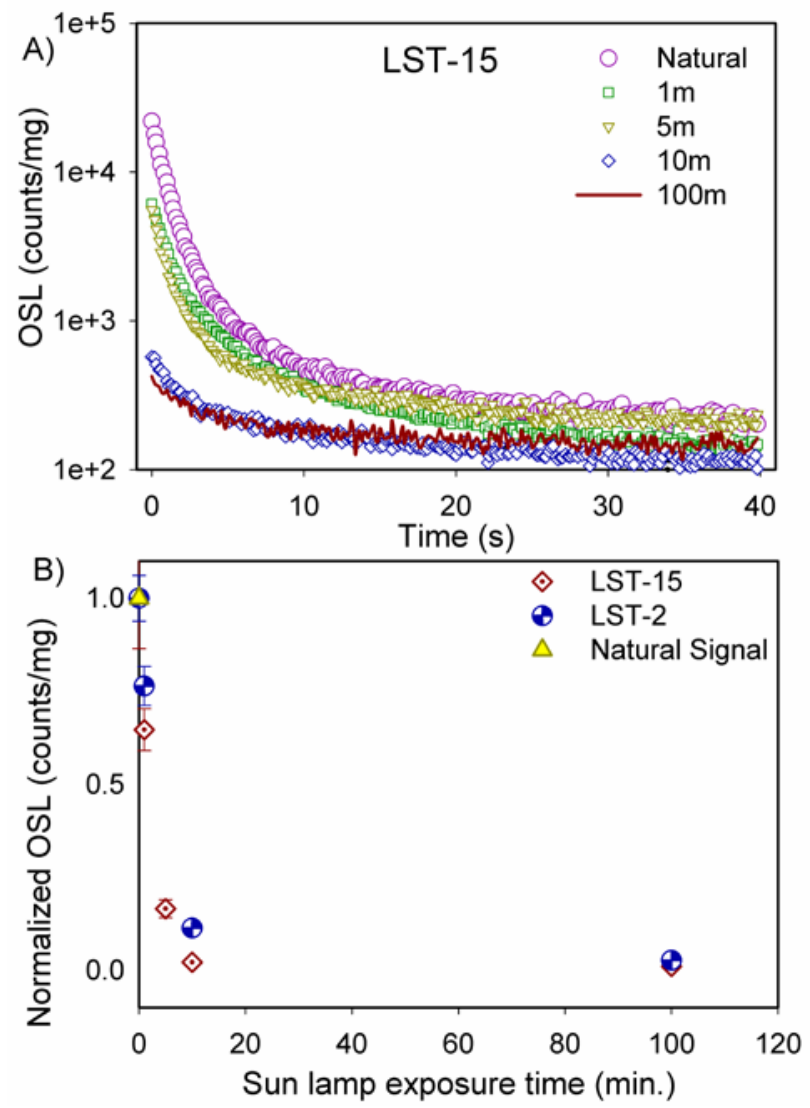

Fig. 6. A) Diagram showing the results of bleaching test with various exposure times for a selected sample. B) The natural signal in the sample is measured and the ratio of weight normalized signal to the natural is obtained at various exposure times to demonstrate the proportion of bleaching at different time intervals from two selected samples. 
The single grain $\mathrm{D}_{\mathrm{e}}$ distributions of a number of samples (LST-15-18, 21) had high over dispersion (OD) values (Table 1). Partial bleaching was ruled out as possible source of scatter based on bleaching experiments as well as the depositional environment of the sands. The beta microdosimetric effects (Mayya et al., 2006) on the apparent scatter in the $\mathrm{D}_{\mathrm{e}}$ distribution was considered as these samples had low concentration of $\mathrm{K}(0.2-0.3 \%)$. However, it was observed that up to $98 \%$ of total sediment dose (for samples from sections MT-I to MT-IV) was the uniform dose rate originating from the $\beta$-, $\gamma$ - dose from $U$ and $T h$ and $\gamma$ - dose from $K$, hence the effect of $\beta$ micro dosimetry from $\mathrm{K}$ is minimal. We consider that either the sensitivity change during the measurement of natural OSL (Singhvi et al., 2011) or distribution of U and $\mathrm{Th}$ is heterogeneous at a grain level could be responsible for a larger than normal overdispersion. This aspect however will require further investigation.

Mobilization of sand requires reduced surface moisture, strong and persistent winds and sand supply. Sand supply is controlled by sea level and preservation of aeolian record occurs during transitional climate from drier to wetter period (Singhvi and Porat, 2008). Muttom being an elevated promontory, overlooking the low lying coastal plain, the dunes here have the potential to preserve stacked records. Samples from the contact zone in the NW-SE transect gave ages between 14 and $12 \mathrm{ka}$. Fig. 2 shows the sampling profiles distributed over the area, in which the OSL ages indicate a dune aggradation episode around 15-12 ka at MT-III, $16 \mathrm{ka}$ at MT-I and between 12-9 ka preserved in the upper part of the Terrace I. Given that the lower part of the dune in this section (MT-III) could not be sampled, it is implicit that $>10 \mathrm{~m}$ of underlying sand was deposited earlier. Radiocarbon ages of two aragonite land snail shells (Gardner, 1981) collected below the red sands in the east coast had given calibrated ages (Jayangondaperumal et al., 2012) between 31,244-28,694 cal yr BP and 26,162-24,081 cal yr BP, which provides an estimate of their antiquity to $>30-9$ ka. Loose sand from the upper part of section MT-III accreted during the last 500 a. Field dispositions and climatic indicators of published records (Table 2) suggest that the gully formation in the upper terrace had started in the area due to enhanced SW monsoon precipitation after $9 \mathrm{ka}$.

Table 2 shows the terrestrial climate records from the region that suggests, three climatic phases, i) Late- Pleistocene to terminal Pleistocene (24-12 ka) dry period, ii) Early Holocene (10-6 ka) humid to hyper- humid phase with intensified SW monsoon and iii) middle- late Holocene (6-2 ka) dry phase.

Table 2. Showing the summary of terrestrial climate records indicating variation in SW monsoon between Late Pleistocene to late Holocene.

\begin{tabular}{|c|c|c|c|c|c|}
\hline & $\begin{array}{l}\text { Time inter- } \\
\text { val (ka) }\end{array}$ & Climatic proxy/ method & Location & Inference & Reference \\
\hline \multirow{7}{*}{ 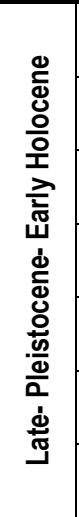 } & $24-18.5$ & Pollens, Peat & $\begin{array}{l}\text { Horton Plains National } \\
\text { Park, Sri Lanka }\end{array}$ & Semi- arid, weak SWM & $\begin{array}{ll}\text { Premathilake } & \text { and } \\
\text { Risberg, } 2003 & \\
\end{array}$ \\
\hline & $20-17$ & Pollens & $\begin{array}{l}\text { Berijam Lake, Palani } \\
\text { hills, S. India }\end{array}$ & Cold and dry climatic conditions & Bera et al., 1995 \\
\hline & $20-11.0$ & $\begin{array}{l}\text { Fluvial and aeolian sequence/ } \\
\text { sedimentology and OSL dating }\end{array}$ & $\begin{array}{l}\text { S. margin of Thar } \\
\text { Desert, India }\end{array}$ & $\begin{array}{l}\text { Aeolian sedimentation, overall dry } \\
\text { climatic condition }\end{array}$ & Juyal et al., 2006 \\
\hline & $20-16$ & $\delta^{13} \mathrm{C},{ }^{14} \mathrm{C}$ dating of peat & Nilgiri Hills, S. India & $\begin{array}{l}\text { Dominance of } \mathrm{C} 4 \text { vegetation, dry } \\
\text { phase }\end{array}$ & Sukumar et al., 1993 \\
\hline & 16 & $\delta^{13} \mathrm{C}$ of peat & Nilgiri Hills, S. India & $\begin{array}{l}\text { Reversal of C3 to C4 type vege- } \\
\text { tation, arid conditions }\end{array}$ & $\begin{array}{l}\text { Rajagopalan et al., } \\
1997\end{array}$ \\
\hline & $14.5-7$ & Pollens & $\begin{array}{l}\text { Berijam Lake, Palani } \\
\text { hills, S. India }\end{array}$ & Warm and humid climate & Bera et al., 1995 \\
\hline & $13.6-12$ & Pollens, Peat & $\begin{array}{l}\text { Horton Plains National } \\
\text { Park, Sri Lanka }\end{array}$ & Humid, Strengthening SWM & $\begin{array}{ll}\text { Premathilake } & \text { and } \\
\text { Risberg, } 2003 & \end{array}$ \\
\hline \multirow{4}{*}{ 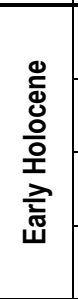 } & $9.9-8.7$ & Pollens, Peat & $\begin{array}{l}\text { Horton Plains National } \\
\text { Park, Sri Lanka }\end{array}$ & Hyper- humid, intensified SWM & $\begin{array}{ll}\text { Premathilake } & \text { and } \\
\text { Risberg, } 2003 & \end{array}$ \\
\hline & 10.6 & $\delta^{13} \mathrm{C},{ }^{14} \mathrm{C}$ dating of peat & Nilgiri Hills, S. India & $\begin{array}{l}\text { Dominance of C3 vegetation, } \\
\text { moist phase, intense SWM }\end{array}$ & Sukumar et al., 1993 \\
\hline & 9 & $\delta^{13} \mathrm{C}$ of peat & Nilgiri Hills, S. India & C3 vegetation- moist phase & $\begin{array}{l}\text { Rajagopalan et al., } \\
1997\end{array}$ \\
\hline & $7-6.0$ & $\begin{array}{l}\text { Lake sediments- } \delta^{13} \mathrm{C},{ }^{14} \mathrm{C} \text { dating, } \\
\text { sed. facies }\end{array}$ & $\begin{array}{l}\text { Lunkaransar Lake, } \\
\text { Thar Desert, India }\end{array}$ & $\begin{array}{l}\text { High lake level, supported by } \\
\text { SWM and excess NEM }\end{array}$ & Enzel et al., 1999 \\
\hline \multirow{3}{*}{ 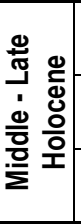 } & $6-3.0$ & ${ }^{13} \mathrm{C},{ }^{14} \mathrm{C}$ dating of peat & Nilgiri Hills, S. India & $\begin{array}{l}\text { Positive excursion of } \delta^{13} \mathrm{C} \text { values } \\
\text { indicating weakened SWM }\end{array}$ & Sukumar et al., 1993 \\
\hline & 5.6 & $\begin{array}{l}\text { Lake sediments- } \delta^{13} \mathrm{C},{ }^{14} \mathrm{C} \text { dating, } \\
\text { sed. facies }\end{array}$ & $\begin{array}{l}\text { Lunkaransar Lake, } \\
\text { Thar Desert, India }\end{array}$ & Desiccation of lake, dry period & Enzel et al., 1999 \\
\hline & $5-2.0$ & $\delta^{13} \mathrm{C},{ }^{14} \mathrm{C}$ dating of peat & Nilgiri Hills, S. India & $\begin{array}{l}\text { Dominance of } \mathrm{C} 4 \text { vegetation, dry } \\
\text { phase }\end{array}$ & $\begin{array}{l}\text { Rajagopalan et al., } \\
1997\end{array}$ \\
\hline
\end{tabular}


It is noticeable from other proxies that the transition to humid period started after $\sim 16$ ka and a hyper humid period occurred at $\sim 9.5 \mathrm{ka}$ due to intensified SW monsoon (Table 2). The OSL age of 16-9 ka for the preserved dune records indicates dune aggradation occurred under this transitional regime and stabilized towards the hyper-humid period. Dune reddening in the area is reported as an in-situ phenomenon (Gardner and Pye, 1981; Pye and Tsoar, 2009), and for the upper horizon it occurred post $\sim 9 \mathrm{ka}$.

The transgression in the south Indian peninsula is marked at $\sim 8-6$ ka BP (Banerjee, 2000 and Rajendran et al., 1989) and as the sea re-captured the exposed sandy areas and depleted the sand supply. Thus the break in dune deposit in this region should have been a response to limited sand availability since $\sim 8 \mathrm{ka}$ until up to $4.5 \mathrm{ka}$. After $\sim 4.5 \mathrm{ka}$, another stage of dune deposition at the lower terrace (seen as consolidated sands at the base of modern loose dune sand), reflects accumulation at a regression phase represented by a number of coast parallel beach ridges, both in east and west coasts (Kunz et al., 2010).

In the east coast, where the major precipitation is received from NE monsoon, the dune deposition shows episodic reactivation since $9 \mathrm{ka}$ to the present. Two sections were sampled at the coastal dunes in the east coast. The eastern section at Neduvankurichi (SK-1) is equivalent to TT1 of Jayangondaperumal et al. (2012), in which they obtained $11.4 \mathrm{ka}$ for a sample at $2 \mathrm{~m}$ depth. This together with results from present study (9-6 ka; SK-1 in Fig. 3), indicates dune accretion between 11-6 $\mathrm{ka}$ in the distal part and $2 \mathrm{~m}$ section at the north central part of the dune complex gave ages of 6-3 ka (SK-2 in Fig. 3), indicating dune activity until up to $3 \mathrm{ka}$, an arid interval reported by other studies (Table 2). Two consecutive samples (LST-21, 22) from SK-1 gave identical ages, which served as an internal check for consistency. It is noteworthy that the wind direction in the region implies that sand supply is not limited by sea level changes and has a different source.

The dunes in the foothills of the W. Ghats are controlled by the source of sand from fluvial and mass wasting processes (Joseph et al., 1997). Two sections (Fig. 3) in this area show at least two stages of deposition. The early stage deposition as seen from profile VK-1 occurred during 5.6-0.1 ka. Considering the positioning of these dunes at the foot hills of W. Ghats and source of sand being fluvial, the cessation of dune formation (marked by distinct slightly indurated stratigraphic unit as well as indicated in the OSL ages) could be attributed to the reduction of sand availability due to declining monsoon in the W. Ghats $\sim 6 \mathrm{ka}$. The unconformity in the section followed by this unit is marked by an indurated brittle calcrete nodular layer. A sand sample from this layer gave OSL age of 2 ka indicating a change in hydrographic conditions after this period. The sand unit above this unconformity showed a modern age between 300-100 years (Fig. 3). Another sample from red sand unit in this area overlying the sand stone basement by Jayangonda- perumal et al. (2012) gave OSL age of 15.4 ka indicating the onset of dune formation. The section at PG-I had shown the dune reactivation during the last millenia with ages ranging from 700-200 years.

\section{CONCLUSIONS}

1) Dune building activity in the west coast between $\sim 30-9$ ka.

2) Dune reddening was favored by the stability due to humid climate.

3) Sand aggradation in the west coast was controlled by sand availability from the on shore source and this was stopped with transgression at $\sim 8 \mathrm{ka}$.

4) Bleaching experiment indicates that $\sim 10 \mathrm{~min}$ of sun exposure of red sand resets to the residual signal in the samples.

5) In the east coast, sand deposition during 9-6 ka and 4-3 ka indicates that the area had continuous sand supply from the exposed river beds and/or from reworking the older dune fields.

6) The unconformity in the inland dunes after $\sim 6 \mathrm{ka}$ suggests reduced sand supply, possibly associated with the general declining monsoon in W. Ghats until up to late Holocene ( $2 \mathrm{ka})$. Sand supply increased thereafter.

\section{ACKNOWLEDGEMENTS}

The authors thank anonymous reviewers for their constructive comments, which helped improving the manuscript. AKS acknowledges Department of Science and Technology (DST), Govt. of India for the award of J.C. Bose National Fellowship.

\section{REFERENCES}

Adamiec G and Aitken MJ, 1998. Dose-rate conversion factors. update. Ancient TL 16: 37-50.

Alappat L, Frechen M, Ramesh R, Tsukamoto S and Srinivasalu S, 2011. Evolution of late Holocene coastal dunes in the Cauvery delta region of Tamil Nadu, India. Journal of Asian Earth Sciences 42(3), 381397, DOI 10.1016/j.jseaes.2011.05.019

Banerjee PK, 2000. Holocene and Late Pleistocene relative sea level fluctuations along the east coast of India. Marine Geology 167(3-4): 243-260, DOI 10.1016/S0025-3227(00)00028-1.

Bera SK, Farooqui A and Gupta HP, 1997. Late Pleistocene-Holocene vegetation and environment in and around Marian Shola, Palni Hills, Tamil Nadu. Palaeobotanist 46: 191-195.

Bera SK, Gupta HP and Farooqui A, 1995. Berijam Lake. 20,000 yrs. Sequence of paleofloristics and paleoenvironment in Palni Hills, South India. Geophytology 26: 99-104.

Berner RA, 1969. Goethite stability and the origin of red beds. Geochimica et Cosmochimica Acta 33(2): 267-273, DOI 10.1016/0016-7037(69)90143-4.

Chandrasekharan S and Murugan C, 2001. Heavy minerals in the beach and the coastal red sands (Teris) of Tamilnadu. Special issue on Beach and Inland Heavy Mineral Sand Deposits of India, Exploration and Research for Atomic Minerals 13: 87-109.

Duff MC, Coughlin JU and Hunter DB, 2002. Uranium co-precipitation with iron oxide minerals. Geochimica et Cosmochimica Acta 66(20): 3533-3547. DOI 10.1016/S0016-7037(02)00953-5. 
Enzel Y, Ely LL, Mishra S, Ramesh R, Amit R, Lazar B, Rajaguru SN, Baker VR and Sandler A, 1999. High-Resolution Holocene Environmental Changes in the Thar Desert, Northwestern India. Science 284(5411): 125-128, DOI 10.1126/science.284.5411.125.

Folk RL, 1976. Reddening of desert sands; Simpson Desert, N. T., Australia. Journal of Sedimentary Research 46(3): 604-615, DOI 10.1306/212F6FFF-2B24-11D7-8648000102C1865D.

Galbraith RF, Roberts RG, Laslett GM, Yoshida H and Olley JM, 1999. Optical dating of single and multiple grains of quartz from Jinmium rock shelter, northern Australia. Part I, experimental design and statistical models. Archaeometry 41(2): 339-364, DOI 10.1111/j.1475-4754.1999.tb00987.x.

Gardner R and Martingell H, 1990. Microlithic sites and their paleoenvironmental setting, Southeast India; a reevaluation. Geoarchaeology 5(1): 1-13, DOI 10.1002/gea.3340050102.

Gardner R and Pye K, 1981. Nature, origin and palaeoenvironmental significance of red coastal and desert dune sands. Progress in Physical Geography 5(4): 514-534, DOI 10.1177/030913338100500402.

Gardner RAM, 1981. Reddening of dune sands - evidence from southeast India. Earth Surface Processes and Landforms 6(5): 459-468, DOI 10.1002/esp.3290060506.

Jayangondaperumal R, Murari MK, Sivasubramanian P, Chandrasekar N and Singhvi AK, 2012. Luminescence dating of fluvial and coastal red sediments in the SE coast, India, and implications for paleoenvironmental changes and dune reddening. Quaternary Research 77(3): 468-481, DOI 10.1016/j.yqres.2012.01.010.

Joseph S, Thrivikramji KP and Anirudhan S, 1999. Mud content, clay minerals and oxidation states of iron inTeris of southern Tamil Nadu. Implication to the origin of Redness. Journal of the Indian Association of Sedimentologist 18: 83-94.

Joseph S, Thrivikramji KP and Babu DSS, 2002. State of alteration of Ilmenite in Teris, southern Tamil Nadu. Journal of Geological Society of India 60: 537-546.

Joseph S, Thrivikramaji KP and Anirudhan S, 1997. Textural parameters, Discriminant analysis and depositional environments of Teri Sands, Southern Tamil Nadu. Journal of Geological Society of India 50: 323-329.

Joseph S and Thrivikramji KP, 2005. Origin of calcretes in Teris, Southern Tamil Nadu. Origin and Paleoenvironmental Implications. Journal of Geological Society of India 65: 158-168.

Juyal N, Chamyal LS, Bhandari S, Bhushan R and Singhvi AK, 2006. Continental record of the southwest monsoon during the last $130 \mathrm{ka}$ : evidence from the southern margin of the Thar Desert, India. Quaternary Science Reviews 25(19-20): 2632-2650. DOI 10.1016/j.quascirev.2005.07.020.

Kumaran KPN, Nair KM, Shindikar M, Limaye RB and Padmalal D, 2005. Stratigraphical and palynological appraisal of the Late Quaternary mangrove deposits of the west coast of India. Quaternary Research 64(3): 418-431. DOI 10.1016/j.yqres.2005.08.015.

Kunz A, Frechen M, Ramesh R and Urban B, 2010. Luminescence dating of late holocene dunes showing remnants of early settlement in Cuddalore and evidence of monsoon activity in south east India. Quaternary International 222(1-2): 194-208, DOI 10.1016/j.quaint.2009.10.042.

Limaye RB, Kumaran KPN, Nair KM and Padmalal D, 2010. Cyanobacteria as potential biomarkers of hydrological changes in the Late Quaternary sediments of South Kerala Sedimentary Basin, India. Quaternary International 213(1-2): 79-90, DOI 10.1016/j.quaint.2009.09.016.

Mayya YS, Morthekai P, Murari MK and Singhvi AK, 2006. Towards quantifying beta microdosimetric effects in single-grain quartz dose distribution. Radiation Measurements 41(7-8), 1032-1039, DOI 10.1016/j.radmeas.2006.08.004

Mejdahl V, 1979. Thermoluminescence dating. Beta dose attenuation in quartz grains. Archaeometry 21(1): 61-63, DOI 10.1111/j.14754754.1979.tb00241.x.

Nageswara Rao K, Udaya Bhaskara Rao C, Vijaya Prakash P and Timma Reddy K, 2006. Morphostratigraphy and evolution of the Quaternary red sands near Bhimunipatnam, east coast of India. Journal of the Geological Society of India 68: 857-873.

Nair KM, Padmalal D, Kumaran KPN, Sreeja R, Limaye RB and Srinivas R, 2010. Late quaternary evolution of Ashtamudi-Sasthamkotta lake systems of Kerala, south west India. Journal of Asian Earth Sciences 37(4): 361-372, DOI 10.1016/i.jseaes.2009.09.004

Padmalal D, Kumaran KPN, Nair KM, Baijulal B, Limaye RB and Mohan SV, 2011. Evolution of the coastal wetland systems of SW India during the Holocene. Evidence from marine and terrestrial archives of Kollam coast, Kerala. Quaternary International 237(1-2): 123139, DOI 10.1016/j.quaint.2010.12.021.

Porat N, 2006. Use of magnetic separation for purifying quartz for luminescence dating Ancient TL 24: 33 .

Premathilake R and Risberg J, 2003. Late Quaternary climate history of the Horton Plains, central Sri Lanka. Quaternary Science Reviews 22(14): 1525-1541, DOI 10.1016/S0277-3791(03)00128-8.

Prescott JR and Hutton JT, 1994. Cosmic ray contributions to dose rates for luminescence and ESR dating. Large depths and long-term time variations. Radiation Measurements 23(2-3): 497-500, DOI 10.1016/1350-4487(94)90086-8.

Pye K and Tsoar H, 2009. Aeolian Sand and Sand Dunes. Berlin, Springer 476

Rajagopalan G, Sukumar R, Ramesh R, Pant RK and Rajagopalan G, 1997. Late Quaternary vegetational and climatic changes from tropical peats in southern India - An extended record up to 40,000 years BP. Current Science 73(1): 60-63.

Rajendran CP, Rajagopalan G and Narayanaswamy, 1989. Quaternary geology of Kerala. evidence from radiocarbon dates. Journal of Geological Society of India 33: 218-222.

Roskin J, Blumberg DG, Porat N, Tsoar H and Rozenstein O, 2012. Do dune sands redden with age? The case of the northwestern Negev dunefield, Israel. Aeolian Research 5: 63-75, DOI 10.1016/j.aeolia.2011.11.004.

Singhvi AK, Deraniyagala SU and Sengupta D, 1986. Thermoluminescence dating of Quaternary red-sand beds. a case study of coastal dunes in Sri Lanka. Earth and Planetary Science Letters 80(1-2): 139-144, DOI 10.1016/0012-821X(86)90027-0.

Singhvi AK and Lang A, 1998. Improvements in infrared stimulated dating of partially bleached sediments-the 'differential' partial bleach technique. Ancient TL 16: 63-71.

Singhvi AK and Porat N, 2008. Impact of luminescence dating on geomorphological and palaeoclimate research in drylands. Boreas 37(4): 536-558, DOI 10.1111/j.1502-3885.2008.00058.x.

Singhvi AK, Stokes S, Chauhan N, Nagar Y and Jaiswal M, 2011. Changes in natural OSL sensitivity during single aliquot regeneration procedure and their implications for equivalent dose determination. Geochronometria 38(3): 231-241, DOI 10.2478/s13386-011-0028-3.

Sukumar R, Ramesh R, Pant RK and Rajagopalan G, 1993. A $\delta^{13}$ C record of late Quaternary climate change from tropical peats in southern India. Nature 364(6439): 703-706, DOI 10.1038/364703a0.

Thrivikramji KP, Joseph S and Anirudhan S, 2008. Teris of Southern Tamil Nadu. Saga of Holocene Climate Change. Memoir Geological Society of India 74: 351-359.

Van Houten FB, 1968. Iron Oxides in Red Beds. Geological Society of America Bulletin 79(4): 399-416, DOI 10.1130/00167606(1968)79[399:IOIRB]2.0.CO;2.

Walker TR, 1967. Formation of Red Beds in Modern and Ancient Deserts. Geological Society of America Bulletin 78(3): 353-368, DOI 10.1130/0016-7606(1967)78[353:FORBIM]2.0.CO;2.

Wintle AG and Murray AS, 2006. A review of quartz optically stimulated luminescence characteristics and their relevance in single-aliquot regeneration dating protocols Radiation Measurements 41(4): 369391, DOI 10.1016/j.radmeas.2005.11.001.

Zhang J, Yuan B and Zhou L, 2008. Luminescence chronology of "Old Red Sand" in Jinjiang and its implications for optical dating of sediments in South China. Chinese Science Bulletin 53(4): 591-601, DOI 10.1007/s11434-008-0001-6.

Zheng W and Wei W, 1998. Formation of "old red sands" and paleogeographic environment on South China coasts. Science in China Series D. Earth Sciences 41: 306-313, DOI 10.1007/BF02973120. 